\title{
Problems, acceptance and social inequality: a study of the deformed leprosy patients and their families
}

\author{
S. N. M. KOPPARTY \\ Centre for Social Science Research on Leprosy, Gandhi Memorial \\ Leprosy Foundation, Hindi Nagar, Wardha-442 103, India
}

\author{
Accepted for publication 25 April 1995
}

\begin{abstract}
Summary Though the impact of social inequality on health conditions is widely known, its impact on the chronic and stigmatized disease, leprosy, has received little attention. Deformity sometimes leads to disabilities and to handicaps causing problems to the patient and his family. In this paper an attempt has been made to understand the impact of social inequality, prevalent in the form of the caste system in India on the deformed leprosy patients and on their families. This impact was examined in terms of the problems faced by the patients. A sample of 150 deformed patients and their families, drawn from two districts in Tamil Nadu, was selected for the study.

About $57 \%$ of the deformed patients experienced their deformity as a handicap which caused social and economic problems while the rest did not. Of the three caste groups, the Lower Caste group experienced more severe economic problems while the Upper Caste group faced more social problems. The extent of acceptance of deformed patients in their family varied significantly among those facing and not facing problems due to their deformity. The deformed patients without any handicap were accepted in a large majority of their families $(82 \%)$ regardless of their caste status. In contrast the deformed but handicapped patients were accepted differentially among the three caste groups with the Upper group accepting them in most of their families $(80 \%)$ while in the Lower group much less number of families (54\%) did. All the families of the deformed but not handicapped patients desired to keep their patients till their death irrespective of their caste status. On the contrary, while all the families in the Upper Caste group expressed their willingness to keep their handicapped patients in the family till their death, $10 \%$ in the Middle and $22 \%$ in the Lower Caste groups did not want to do so. This suggests the gradual marginalization, rejection and dehabilitation of the affected. Thus, one's caste status can be a broad indicator of the nature and the extent of handicaps and acceptance in the family. This factor needs to be appropriately taken care of for rehabilitation and disability management in leprosy control programmes.
\end{abstract}

\section{Introduction}

Social inequality in India is widely prevalent through a caste system. A caste system is 
one whereby a society is divided into a number of self-contained units (castes), the mutual relations between which are ritually determined in a graded scale. ${ }^{1} \mathrm{~A}$ caste is a social group that follows a traditional occupation, observes eating of prescribed foods, restricts a person to marry within the same caste, limits social interaction and prohibits higher caste individuals from being 'polluted' by contact with Lower Caste individuals. $^{2-4}$ Caste status reflects the customs, values, occupations, accessibility or denial to various resources including health, life-style and culture of a group which is sometimes in marked contrast to others. ${ }^{5}$ It is a broad indicator of the social, economic and ritual status that a group enjoys in the society. There are about 3000 castes in India. The impact ${ }_{3}$ of socioeconomic inequalities on the health conditions of population has been well documented. ${ }^{6-10}$ However, very little is known about the influence of caste on morbidity ${ }^{11-14}$ and even less, in a stigmatized disease like leprosy. ${ }^{15-16}$

About two-thirds of leprosy patients registered in the world are in India. ${ }^{17}$ Between 5 and $15 \%$ of them are deformed. ${ }^{18}$ Together with the already deformed, but not with active disease the number of persons deformed due to leprosy in the country is much greater. Deformity is the most dreaded state in leprosy. It often leads to disabilities. Disability refers to any restriction or lack of ability to perform an activity that results from deformity. Deformity or disability may lead to a 'handicap' which refers to a disadvantage for a given individual that limits or prevents the fulfilment of the normal role of the individual. ${ }^{19-20}$ While deformity may cause a handicap to some, it may not do so to others. It is closely related to one's social characteristics such as social status, occupation, age, sex etc. The meaning of handicap, therefore, changes as per a given social situation. ${ }^{21-22}$

Deformity or handicap has considerable impact on the life of the affected in terms of general well-being, adjustment and happiness. Leprosy is known to cause economic, social and psychological problems and more so, if it is associated by deformities and handicaps. ${ }^{23-29}$ The problems caused by a handicap due to leprosy will affect acceptance by the individual's own family, subsequently leading to marginalization, rejection and dehabilitation, depending upon the nature of handicap. The manifestation of deformity into a handicap and its impact on the affected and their family depends broadly upon the values, occupation, economic resources and life-style of the caste group to which they belong. This paper seeks to understand the impact of the caste system on the nature and extent of problems faced by deformed leprosy patients.

\section{Materials and methods}

Two districts - one with a high prevalence (South Arcot P.R. 16.4/1000), and the other with a low prevalence (Kanyakumari P.R. 48/1000) —of Tamil Nadu were selected for the study conducted in 1989-90. Both the districts were under monotherapy at the time of investigation. In each district two leprosy control units (LCU)—one in a rural area and the other in an urban area-were selected using the same prevalence criterion. A sample of 500 patients and their families drawing 125 from each control unit were selected through systematic random sampling methods.

Of these, 150 patients had deformities. The data on the deformed patients and their families are analysed in depth in this paper. Data were collected through interview schedules and informal interviews. The caste status of all the families was categorized 
into Upper, Middle and Lower Groups based on the ritual and social status, as determined by a group of well-informed individuals in the community. Thus, (i) the Upper Group consisted of ritually pure, economically, educationally and socially advanced castes, (ii) the Lower Group comprised of untouchable castes which are ritually impure, poor, landless, illiterate, residentially segregated, and engaged in low paid occupations, and (iii) the Middle Group consisted of the rest of the castes which are treated as ritually pure, mostly small peasants, artisans, and the less literate.

The status of the patients was categorized into 'non-deformed' comprising of mere patches or nodules and 'deformed' consisting of change in form, loss of functioning or loss of any part of the body. The deformity was further categorized into a handicap or a non-handicap depending on the patient's self-reporting about the nature of problems it causes him in his daily living.

\section{Results}

Of the total sample of 500 patients, the Upper, Middle and Lower Caste groups formed $11 \cdot 2 \%, 61 \cdot 8 \%$ and $27 \%$, respectively, which corresponds closely to their respective proportion in the general population. However, the proportion of deformed patients differ significantly among the three caste groups. The Upper Caste group had a comparatively smaller proportion of deformed patients $(19.6 \%)$ than the Middle Caste $(33 \%)$ and Lower Caste $(27 \cdot 4 \%)$ groups. Furthermore, the deformed patients who became handicapped also varied in the three caste groups. While there were only $9 \%$ of the patients handicapped in the Upper Caste group, it was 17.4 and $20 \%$ in the Middle and Lower Caste groups, respectively. Thus, the proportion of handicapped progressively increased from the Upper to Lower Caste groups (Table 1).

Of the 150 deformed patients, 86 patients $(57 \cdot 3 \%)$ found their deformity to be a handicap in employment, or when participating in community activities etc. When the employment of the patients was affected, their family faced economic problems often depriving them of their daily necessities. Similarly, they were not well received by their friends, relatives, neighbours and were not invited to community functions. The marital prospects of patients themselves or their family members were also affected. In contrast, the remaining 64 patients $(42 \cdot 7 \%)$ did not experience their deformity as a handicap and as a result did not face any problems.

The social and medical characteristics of the handicapped (HP) and non-handicapped

Table 1. Distribution of non-deformed and deformed leprosy patients in caste groups

\begin{tabular}{lcccr}
\hline Status & Lower Castes & Middle Castes & Upper Castes & Total \\
\hline Non-deformed patients & $98(72 \cdot 6)^{*}$ & $207(67 \cdot 0)$ & $45(80 \cdot 3)$ & $350(70 \cdot 0)$ \\
Deformed patients & & & & \\
$\quad$ Non-handicapped & $27(20 \cdot 0)$ & $54(17 \cdot 4)$ & $5(08 \cdot 9)$ & $86(17 \cdot 2)$ \\
$\quad$ Handicapped & $10(07 \cdot 4)$ & $48(15 \cdot 5)$ & $6(10 \cdot 7)$ & $64(12 \cdot 8)$ \\
Total & $135(27)$ & $309(61 \cdot 8)$ & $56(11 \cdot 2)$ & $500(100)$ \\
\hline
\end{tabular}

\footnotetext{
* Percentage in parentheses.
} 
Table 2. Medical and social characteristics of handicapped and nonhandicapped leprosy patients

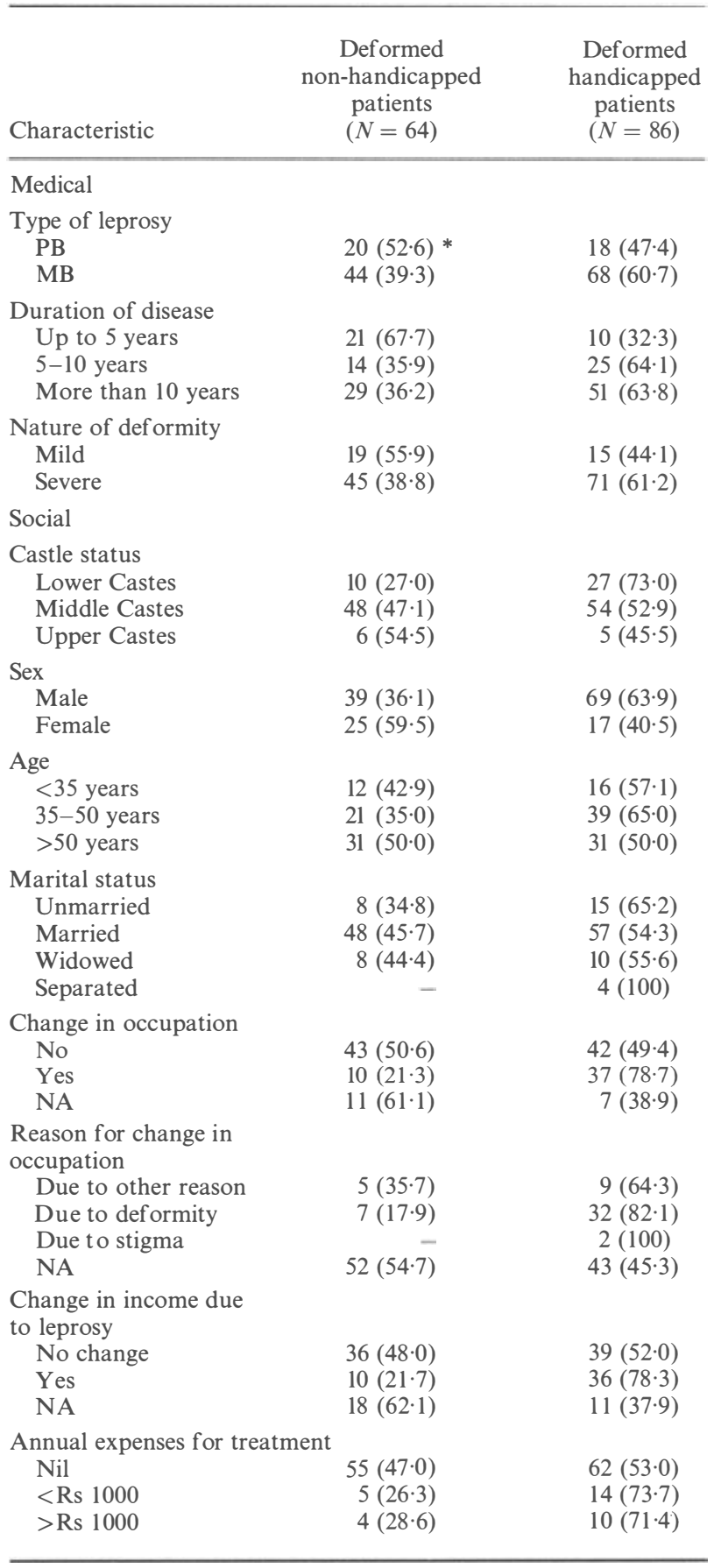

* Percentage in parentheses. 
(NHP) patients are presented in Table 2. A larger number of handicapped than nonhandicapped patients were males (HP 63.9\%, NHP 36.1\%), unmarried (HP 65.2\%, NHP $34.8 \%$ ), changed occupation (HP 78.7\%, NHP $21 \cdot 3 \%$ ) and of a productive age group (35-50 years, HP $65 \%$, NHP 35\%). Further, of those whose income declined due to leprosy and who spent about thousand rupees or more annually for treatment, threequarters of them were handicapped. The medical characteristics show that a larger number of handicapped patients than non-handicapped patients had multibacillary leprosy (HP 60.7\%, NHP 39.3\%) and had suffered for more than 10 years (HP $63 \cdot 8 \%$, NHP $36 \cdot 3 \%$ ) and were severely deformed (HP 61.2\%, NHP 38.8\%).

The problems faced by the families of the handicapped deformed patients were economic and social in nature. The economic problems faced include: 1, loss of main source of income because of loss of occupation; 2 , loss of additional source of income; 3 , loss of savings; and 4, incurring debt to meet the family expenditure. The social problems were: 1 , denial of participation in community activities; 2 , dislike by relatives, friends, villagers etc; and 3, diminished marital prospects of the patients or their family members. A considerable proportion of families $(31 \cdot 3 \%)$ faced some economic problems only while a small proportion of families $(6 \cdot 7 \%)$ faced some social problems only. On the otherhand, there were families which faced some economic and some social problems together $(13 \cdot 3 \%)$. Still further, some families faced all aspects of both economic and social problems listed above $(6 \cdot 0 \%)$ (Table 3$)$.

Of the three caste groups, a large majority of the deformed patients in the Lower Caste group faced economic and social problems (73\%) compared to a comparatively lesser number in the Middle (53\%) and the Upper Caste (45.5\%) groups. The nature and magnitude of problems faced differed significantly in the three caste groups. While the handicapped patients in the Lower Caste group faced exclusively economic problems in a greater proportion $(43.2 \%)$, fewer in the Middle Caste $(29 \cdot 4 \%)$ and the least in the Upper Caste groups $(9 \cdot 1 \%)$ did so. In contrast, the exclusively social problems faced by the patients and their families, progressively increased from Lower $(2 \cdot 7 \%)$ to Middle $(6 \cdot 9 \%)$ and to Upper Caste $(18.2 \%)$ groups. Similar observations can be made in the case of the handicapped patients facing partly economic and partly social problems. It is

Table 3. Distribution of families with handicapped patients facing problems and families without handicapped patients in Caste groups

\begin{tabular}{lcccr}
\hline Type of family & Lower Castes & Middle Castes & Upper Castes & Total \\
\hline $\begin{array}{l}\text { Families without handicapped } \\
\text { patients (no problems) }\end{array}$ & $10(27 \cdot 0)^{*}$ & $48(47 \cdot 1)$ & $6(54 \cdot 5)$ & $64(42 \cdot 7)$ \\
$\begin{array}{l}\text { Families with handicapped } \\
\text { patients (f acing problems) }\end{array}$ & & & & \\
$\quad$ Economic & $16(43 \cdot 2)$ & $30(29 \cdot 4)$ & $1(09 \cdot 1)$ & $47(31 \cdot 3)$ \\
$\quad$ Social & $1(02 \cdot 7)$ & $7(0 \cdot 69)$ & $2(18 \cdot 2)$ & $10(06 \cdot 7)$ \\
$\quad \begin{array}{l}\text { Partly social \& } \\
\text { partly economic }\end{array}$ & $4(10 \cdot 8)$ & $14(13 \cdot 7)$ & $2(18 \cdot 2)$ & $20(13 \cdot 3)$ \\
$\quad$ All together & $6(16 \cdot 2)$ & $3(02 \cdot 9)$ & $11(100)$ & $-106 \cdot 0)$ \\
Total & $37(100)$ & $102(100)$ & $150(100)$ \\
\hline
\end{tabular}

* Percentage in parentheses.

$\chi$-square $=18.61 \quad P=0.01$. 
significant to note that a sizeable proportion of handicapped patients in the Lower Caste group $(16 \cdot 2 \%)$ faced all dimensions of both economic and social problems while a negligible proportion of patients from the Middle Caste $(2 \cdot 9 \%)$ group faced such problems. On the other hand, there was not even a single family in the Upper Caste group which faced all problems together.

While the families of the Lower Caste group were the worst affected by economic problems, the Upper Caste group families experienced comparatively greater social problems. This is shown by the annual income of the handicapped patients and the extent and reasons for change in their occupation (Tables 4 and 5). Most of the handicapped patients in the Lower Caste group $(85.2 \%)$ were concentrated in the lowest income bracket of less than Rs. 2500 per annum while only $50 \%$ in the Middle and $20 \%$ in the Upper Caste Groups were in the same bracket. Similarly, two-thirds of the handicapped patients in the Lower Caste group $(66.7 \%)$ changed their occupation due to deformity while only $24 \%$ in the Middle and $20 \%$ in the Upper Caste groups did so. Generally, change in occupation leads to accepting less demanding and less remunerative work resulting in a fall in income which leads to economic problems.

In contrast, the Upper Caste families faced more social problems because of their higher social status in the society. This suggests that there is greater stigma in the Upper Caste group than in the Lower Caste group. Thus, the nature and extent of problems faced by the Upper and Lower Caste groups varied considerably.

Selected aspects of the acceptance of the handicapped and non-handicapped patients in their family was examined, e.g. the sharing of clothes, use of dining place, participation in decision making, participation in functions in the family, dining with other

Table 4. Distribution of handicapped (HP) and non-handicapped patients (NHP) in income (annual) categories among Caste groups

\begin{tabular}{|c|c|c|c|c|c|}
\hline $\begin{array}{l}\text { Annual } \\
\text { income } \\
\text { (Rupees) }\end{array}$ & $\begin{array}{c}\text { Patients } \\
\text { Non-Handi (NHP) } \\
\text { Handi (HP) }\end{array}$ & $\begin{array}{l}\text { Lower } \\
\text { Castes }\end{array}$ & $\begin{array}{l}\text { Middle } \\
\text { Castes }\end{array}$ & $\begin{array}{l}\text { Upper } \\
\text { Castes }\end{array}$ & Total \\
\hline$<2500$ & $\begin{array}{r}\text { NHP } \\
\text { HP }\end{array}$ & $\begin{array}{c}5(50 \cdot 0)^{*} \\
23(85 \cdot 2)\end{array}$ & $\begin{array}{l}27(56 \cdot 2) \\
27(50 \cdot 0)\end{array}$ & $\begin{array}{l}2(33 \cdot 3) \\
1(20 \cdot 0)\end{array}$ & $\begin{array}{l}34(53 \cdot 1) \\
51(59 \cdot 3)\end{array}$ \\
\hline $2501-5000$ & $\begin{array}{r}\text { NHP } \\
\text { HP }\end{array}$ & $\begin{array}{l}1(10 \cdot 0) \\
2(07 \cdot 4)\end{array}$ & $\begin{array}{l}3(06 \cdot 2) \\
9(16 \cdot 7)\end{array}$ & $\begin{array}{r}1(16 \cdot 7) \\
-\end{array}$ & $\begin{array}{r}5(07 \cdot 8) \\
11(12 \cdot 8)\end{array}$ \\
\hline $5001-10,000$ & $\begin{array}{r}\text { NHP } \\
\text { HP }\end{array}$ & $\begin{array}{l}3(30 \cdot 0) \\
2(07 \cdot 4)\end{array}$ & $\begin{array}{l}14(29 \cdot 2) \\
13(24 \cdot 1)\end{array}$ & $\begin{array}{l}2(33 \cdot 3) \\
2(40 \cdot 0)\end{array}$ & $\begin{array}{l}19(29 \cdot 7) \\
17(19 \cdot 8)\end{array}$ \\
\hline $10,001-25,000$ & $\begin{array}{r}\text { NHP } \\
\text { HP }\end{array}$ & $\begin{array}{r}1(10 \cdot 0) \\
-\end{array}$ & $\begin{array}{l}2(04 \cdot 2) \\
5(09 \cdot 2)\end{array}$ & $\begin{array}{l}1(16 \cdot 7) \\
1(20 \cdot 0)\end{array}$ & $\begin{array}{l}4(06 \cdot 2) \\
6(07 \cdot 0)\end{array}$ \\
\hline$>25,000$ & $\begin{array}{r}\text { NHP } \\
\text { HP }\end{array}$ & $\begin{array}{l}- \\
-\end{array}$ & $\begin{array}{r}2(04 \cdot 2) \\
=\end{array}$ & $1(20 \cdot 0)$ & $\begin{array}{l}2(03 \cdot 2) \\
1(01 \cdot 1)\end{array}$ \\
\hline Total & $\begin{array}{r}\text { NHP } \\
\text { HP }\end{array}$ & $\begin{array}{l}10(100 \cdot 0) \\
27(100 \cdot 0)\end{array}$ & $\begin{array}{l}48(100 \cdot 0) \\
54(100 \cdot 0)\end{array}$ & $\begin{array}{l}6(100 \cdot 0) \\
5(100 \cdot 0)\end{array}$ & $\begin{array}{l}64(100 \cdot 0) \\
86(100 \cdot 0)\end{array}$ \\
\hline Grand Total & & 37 & 102 & 11 & 150 \\
\hline
\end{tabular}

* Percentage in parentheses.

$\chi$-square NHP $3.66060 \quad P \cdot 9614$.

HP $30.35720 \quad P \cdot 0002$. 
members in the family etc. In general, non-handicapped patients were accepted in a larger number of families $(82 \cdot 3 \%)$ than handicapped patients $(64 \%)$. This shows that as long as the deformity does not turn out to become a handicap, the deformed patients were accepted more widely than the handicapped. Table 6 details the acceptance of handicapped and non-handicapped patients in different social aspects. In some aspects both the handicapped and non-handicapped patients were accepted to the same extent while there was a wide difference in others. For example, with regard to taking meals with other family members only $50 \%$ of the patients were allowed to eat with other family members, regardless of their handicap. Similarly, for accompanying patients to the clinic only $30 \%$ of the families extended their support to the patients. In other aspects, the differences varied considerably. While only $40 \%$ of the handicapped patients were allowed by their families to do their household duties as expected of their role, such as participation in functions, visiting relatives etc, $81 \%$ were allowed in the case of nonhandicapped patients. Similar findings, though to a much lesser extent, can be seen with regard to the sharing of bedding of the patient by other family members (NHP $92 \cdot 2 \%$, HP 59.3\%), sharing of clothes (NHP 89.1\%, HP 60.5\%), participation in family celebrations (NHP 93.8\%, HP 65.1\%), use of dining place (HP 95.3\%, NHP 75.6\%), mixing freely with other family members (NHP 98.4\%, HP 79.1\%) etc. While all families wanted to keep their non-handicapped patients till their death, only $86 \%$ of families of handicapped patients wanted to do so. This means that $14 \%$ of handicapped patients are in the process of marginalization which may lead to rejection and dehabilitation.

Of the three caste groups, a slightly greater number of families in the Lower Caste group $(87 \%)$ accepted their non-handicapped patients than the Middle $(81 \cdot 2 \%)$ and Upper (83.3\%) Caste groups. In contrast, a larger number of families in the Upper Caste group (80\%) accepted their handicapped patients than the Middle (65.4\%) and Lower Caste $(54.4 \%)$ groups. This shows that while the non-handicapped patients were widely

Table 5. Reason for change in occupation by the handicapped (HP) and non-handicapped (NHP) leprosy patients in caste groups

\begin{tabular}{|c|c|c|c|c|c|}
\hline Reason & $\begin{array}{c}\text { Patients } \\
\text { Non-Handi (NHP) } \\
\text { Handi (HP) }\end{array}$ & $\begin{array}{l}\text { Lower } \\
\text { Castes }\end{array}$ & $\begin{array}{l}\text { Middle } \\
\text { Castes }\end{array}$ & $\begin{array}{l}\text { Upper } \\
\text { Castes }\end{array}$ & Total \\
\hline Deformity & $\begin{array}{r}\text { NHP } \\
\text { HP }\end{array}$ & $\begin{array}{l}2(20 \cdot 0) * \\
18(66 \cdot 7)\end{array}$ & $\begin{array}{r}5(10 \cdot 4) \\
13(24 \cdot 1)\end{array}$ & $1(20 \cdot 0)$ & $\begin{array}{r}7(10 \cdot 9) \\
32(37 \cdot 2)\end{array}$ \\
\hline Stigma & $\begin{array}{r}\text { NHP } \\
\text { HP }\end{array}$ & $\begin{array}{l}- \\
-\end{array}$ & $2(03 \cdot \overline{7})$ & - & $2(02 \cdot 3)$ \\
\hline Other reasons & $\begin{array}{r}\text { NHP } \\
\text { HP }\end{array}$ & $1(03 \cdot \overline{7})$ & $\begin{array}{l}3(06 \cdot 3) \\
8(14 \cdot 8)\end{array}$ & $\begin{array}{r}2(33 \cdot 3) \\
-\end{array}$ & $\begin{array}{l}5(07 \cdot 8) \\
9(10 \cdot 5)\end{array}$ \\
\hline NA & $\begin{array}{r}\text { NHP } \\
\text { HP }\end{array}$ & $\begin{array}{l}8(80 \cdot 0) \\
8(29 \cdot 6)\end{array}$ & $\begin{array}{l}40(83 \cdot 3) \\
31(57 \cdot 4)\end{array}$ & $\begin{array}{l}4(66 \cdot 7) \\
4(80 \cdot 0)\end{array}$ & $\begin{array}{l}52(81 \cdot 3) \\
43(50 \cdot 0)\end{array}$ \\
\hline Total & $\begin{array}{r}\text { NHP } \\
\text { HP }\end{array}$ & $\begin{array}{l}10(100 \cdot 0) \\
27(100 \cdot 0)\end{array}$ & $\begin{array}{l}48(100 \cdot 0) \\
54(100 \cdot 0)\end{array}$ & $\begin{array}{l}6(100 \cdot 0) \\
5(100 \cdot 0)\end{array}$ & $\begin{array}{l}64(100 \cdot 0) \\
86(100 \cdot 0)\end{array}$ \\
\hline Grand total & & 37 & 102 & 11 & 150 \\
\hline
\end{tabular}

\footnotetext{
* Percentage in parentheses.

$\chi$-square NHP 7.53700 $\quad P \cdot 1101$. 
accepted irrespective of their caste status, the handicapped patients were accepted less and less from Upper to Lower Caste groups. This indicates that the magnitude of the impact of handicap differs and increases progressively from Upper to Lower Caste group. The differential in acceptance of handicapped patients among the three caste groups is more striking in some individual aspects such as sharing of.clothes, use of common dining place etc (Table 6).

While all the families of non-handicapped patients regardless of their caste status wanted to keep their patients with them till their death, only $77 \%$ of the families of the handicapped in the Lower and $89 \%$ in the Middle Caste groups desired to do so. In

Table 6. Number of families accepting their handicapped (FHP) or non-handicapped (FNHP) leprosy patients in selected aspects

\begin{tabular}{|c|c|c|c|c|c|}
\hline $\begin{array}{l}\mathrm{Fa} \\
\mathrm{No} \\
\text { Han }\end{array}$ & $\begin{array}{c}\text { Families with } \\
\text { Non-Handi Pat } \\
\text { (FNHP) } \\
\text { Handi Pat (FHP) }\end{array}$ & $\begin{array}{c}\text { Lower } \\
\text { Castes } \\
\text { NHP }(N=10) \\
\text { HP }(N=27)\end{array}$ & $\begin{array}{c}\text { Middle } \\
\text { Castes } \\
\text { NHP }(N=48) \\
\text { HP }(N=54)\end{array}$ & $\begin{array}{c}\text { Upper } \\
\text { Castes } \\
\text { NHP }(N=6) \\
\text { HP }(N=5)\end{array}$ & $\begin{array}{c}\text { Total } \\
\text { NHP }(N=64) \\
\operatorname{HP}(N=86)\end{array}$ \\
\hline $\begin{array}{l}\text { Sharing of clothes } \\
\text { with the patient }\end{array}$ & $\begin{array}{l}\text { FNHP } \\
\text { FHP }\end{array}$ & $\begin{array}{l}10(100)^{*} \\
12(44 \cdot 4)\end{array}$ & $\begin{array}{l}42(87 \cdot 5) \\
36(66 \cdot 7)\end{array}$ & $\begin{array}{l}5(83 \cdot 3) \\
4(80 \cdot 0)\end{array}$ & $\begin{array}{l}57(89 \cdot 1) \\
52(60 \cdot 5)\end{array}$ \\
\hline $\begin{array}{l}\text { No separate bedding } \\
\text { provided to the patient }\end{array}$ & $\begin{array}{l}\text { FNHP } \\
\text { FHP }\end{array}$ & $\begin{array}{l}10(100) \\
12(44 \cdot 4)\end{array}$ & $\begin{array}{l}43(89 \cdot 6) \\
35(64 \cdot 8)\end{array}$ & $\begin{array}{l}5(83 \cdot 3) \\
4(80 \cdot 0)\end{array}$ & $\begin{array}{l}58(90 \cdot 6) \\
51(59 \cdot 3)\end{array}$ \\
\hline $\begin{array}{l}\text { Patient allowed to use } \\
\text { common dining place }\end{array}$ & $\begin{array}{l}\text { FNHP } \\
\text { FHP }\end{array}$ & $\begin{array}{l}10(100) \\
14(51 \cdot 9)\end{array}$ & $\begin{array}{l}45(93 \cdot 8) \\
46(85 \cdot 2)\end{array}$ & $\begin{array}{l}6(100) \\
5(100)\end{array}$ & $\begin{array}{l}61(95 \cdot 3) \\
65(75 \cdot 6)\end{array}$ \\
\hline $\begin{array}{l}\text { Allowed to take meals } \\
\text { with other family } \\
\text { members always }\end{array}$ & $\begin{array}{l}\text { FNHP } \\
\text { FHP }\end{array}$ & $\begin{array}{r}6(60 \cdot 0) \\
13(48 \cdot 1)\end{array}$ & $\begin{array}{l}24(50 \cdot 0) \\
26(48 \cdot 1)\end{array}$ & $\begin{array}{l}3(50 \cdot 0) \\
4(80 \cdot 0)\end{array}$ & $\begin{array}{l}33(51 \cdot 6) \\
43(50 \cdot 0)\end{array}$ \\
\hline $\begin{array}{l}\text { Never discouraged } \\
\text { patient mixing freely } \\
\text { with other family membe }\end{array}$ & $\begin{array}{l}\text { FNHP } \\
\text { FHP } \\
\text { ers }\end{array}$ & $\begin{array}{l}10(100) \\
21(77 \cdot 8)\end{array}$ & $\begin{array}{l}47(97 \cdot 9) \\
43(79 \cdot 6)\end{array}$ & $\begin{array}{l}6(100) \\
4(80 \cdot 0)\end{array}$ & $\begin{array}{l}63(98 \cdot 4) \\
68(79 \cdot 1)\end{array}$ \\
\hline $\begin{array}{l}\text { Allowed in decision } \\
\text { making in the family } \\
\text { as before occurance of } \\
\text { the disease }\end{array}$ & $\begin{array}{l}\text { FNHP } \\
\text { FHP }\end{array}$ & $\begin{array}{l}10(100) \\
19(70 \cdot 4)\end{array}$ & $\begin{array}{l}44(91 \cdot 7) \\
46(85 \cdot 2)\end{array}$ & $\begin{array}{l}6(100) \\
4(80 \cdot 0)\end{array}$ & $\begin{array}{l}60(93 \cdot 8) \\
69(80 \cdot 2)\end{array}$ \\
\hline $\begin{array}{l}\text { Allowed to participate } \\
\text { in family celebrations as } \\
\text { before occurrence of the } \\
\text { disease }\end{array}$ & $\begin{array}{l}\text { FNHP } \\
\text { FHP }\end{array}$ & $\begin{array}{l}10(100) \\
16(59 \cdot 3)\end{array}$ & $\begin{array}{l}44(91 \cdot 7) \\
36(66 \cdot 7)\end{array}$ & $\begin{array}{l}6(100) \\
4(80 \cdot 0)\end{array}$ & $\begin{array}{l}60(93 \cdot 8) \\
56(65 \cdot 1)\end{array}$ \\
\hline $\begin{array}{l}\text { Allowed to perform all } \\
\text { household duties as } \\
\text { before occurrence of the } \\
\text { disease }\end{array}$ & $\begin{array}{l}\text { FNHP } \\
\text { FHP }\end{array}$ & $\begin{array}{l}8(80 \cdot 0) \\
12(44 \cdot 4)\end{array}$ & $\begin{array}{l}38(79 \cdot 2) \\
19(35 \cdot 2)\end{array}$ & $\begin{array}{l}6(100) \\
3(60 \cdot 0)\end{array}$ & $\begin{array}{l}52(81 \cdot 3) \\
34(39 \cdot 5)\end{array}$ \\
\hline $\begin{array}{l}\text { Family members help in } \\
\text { accompanying patient } \\
\text { to clinic invariably }\end{array}$ & $\begin{array}{l}\text { FNHP } \\
\text { FHP }\end{array}$ & $\begin{array}{l}3(30 \cdot 0) \\
5(18 \cdot 5)\end{array}$ & $\begin{array}{l}15(31 \cdot 3) \\
18(33 \cdot 3)\end{array}$ & $\begin{array}{l}1(16 \cdot 7) \\
3(60 \cdot 0)\end{array}$ & $\begin{array}{l}19(29 \cdot 7) \\
26(30 \cdot 2)\end{array}$ \\
\hline $\begin{array}{l}\text { Wishing to keep the } \\
\text { patient in the family } \\
\text { until death }\end{array}$ & $\begin{array}{l}\text { FNHP } \\
\text { FHP }\end{array}$ & $\begin{array}{l}10(100) \\
21(77 \cdot 8)\end{array}$ & $\begin{array}{l}48(100) \\
48(88.9)\end{array}$ & $\begin{array}{l}6(100) \\
5(100)\end{array}$ & $\begin{array}{l}64(100) \\
74(86 \cdot 0)\end{array}$ \\
\hline Mean & $\begin{array}{l}\text { FNHP } \\
\text { FHP }\end{array}$ & $\begin{array}{r}8 \cdot 7(87 \cdot 0) \\
14 \cdot 7(54 \cdot 4)\end{array}$ & $\begin{array}{l}39(81 \cdot 2) \\
35 \cdot 3(65 \cdot 4)\end{array}$ & $\begin{array}{l}5(83 \cdot 3) \\
4(80 \cdot 0)\end{array}$ & $\begin{array}{l}52 \cdot 7(82 \cdot 3) \\
55 \cdot 0(64 \cdot 0)\end{array}$ \\
\hline
\end{tabular}

\footnotetext{
* Percentage in parentheses.
} 
Table 7. Number of families accepting or not accepting the handicapped and nonhandicapped patients in selected aspects

\begin{tabular}{lccc}
\hline Status & $\begin{array}{c}\text { Handicapped } \\
\text { patients }\end{array}$ & $\begin{array}{c}\text { Non-handicapped } \\
\text { patients }\end{array}$ & Total \\
\hline Accepted & $54(62 \cdot 8)^{*}$ & $53(82 \cdot 8)$ & $107(71 \cdot 3)$ \\
Not accepted & $32(37 \cdot 2)$ & $11(17 \cdot 2)$ & $43(28 \cdot 7)$ \\
Total & $86(100)$ & $64(100)$ & $150(100)$ \\
\hline
\end{tabular}

$*$ Percentage in parentheses.
$\chi$-square $=7 \cdot 1932 \quad P=\cdot 01$

contrast, all the families in the Upper Caste group desired to keep their handicapped patients till their death. This shows that about a quarter of the handicapped patients in the Lower Caste group were in the process of marginalization and dehabilitation while it is much less $(10 \%)$ in the Middle Caste group. The economic hardship coupled with low social status facilitates marginalization, rejection and dehabilitation of the patients in the Lower Caste group. The extent of acceptance in the family and the status of deformity (handicap and non-handicap) of the patients is significantly associated $(P=0.01)$ (Table 7). The number of families accepting the handicapped patients decreased from the Upper $(80 \%)$ to Lower $(55 \%)$ Caste groups (Table 8$)$.

\section{Discussion}

Deformity due to leprosy affected the three Caste groups in different ways. While deformity was experienced as a handicap by three-quarters of the patients in the Lower Caste group it was much less so in the Middle (53\%) and still less in the Upper Caste $(45 \%)$ groups. The nature and severity of the impact of handicap also differed widely. While the handicap caused economic problems in $96 \%$ of the families in the Lower Caste group it did so less in the Middle (87\%) and much less in the Upper (60\%) Caste groups. In contrast, while the handicap caused social problems in about $40-44 \%$ of the families of Lower and Middle Caste groups, it did so almost twice as much (80\%) in the Upper Caste group. While the handicapped patients in the Lower Caste group mostly faced economic problems, those in the Upper Caste group mostly faced social problems. The Middle Caste group was closer to the Lower Caste group in facing economic and social problems though in slightly lesser magnitude.

Table 8. Number of families accepting or not accepting their handicapped patients in Caste groups

\begin{tabular}{lcccc}
\hline Status & $\begin{array}{c}\text { Lower } \\
\text { Castes }\end{array}$ & $\begin{array}{c}\text { Middle } \\
\text { Castes }\end{array}$ & $\begin{array}{l}\text { Upper } \\
\text { Castes }\end{array}$ & Total \\
\hline Accepted & $15(55 \cdot 6)^{*}$ & $35(64 \cdot 8)$ & $4(80 \cdot 0)$ & $54(62 \cdot 8)$ \\
Not accepted & $12(44 \cdot 4)$ & $19(35 \cdot 2)$ & $1(20 \cdot 0)$ & $32(37 \cdot 2)$ \\
Total & $27(100)$ & $54(100)$ & $5(100)$ & $86(100)$ \\
\hline
\end{tabular}

\footnotetext{
* Percentage in parentheses.
} 
In terms of acceptance, the deformed patients without any handicap were accepted in most of the families $(82 \%)$. Their acceptance dwindled down $(64 \%)$ once the deformity became a handicap. The handicapped were accepted differently in the three caste groups with the Upper Caste group accepting them in a larger number of their families $(80 \%)$ than the Middle (65.4\%) and Lower (54\%) Caste groups. The differing acceptance may be attributed to the life-chances of the three caste groups. The Lower Caste group is mostly landless, poor and dependent on physical labour largely in agriculture, industry etc. Deformities can thus become handicaps more easily, manif ested by occupational change incurring debt, depletion of savings etc. On the other hand, this is less true in the Upper Caste group as they have more reserve resources and opportunities. Also the Upper Caste group seems to attach greater value to prestige and status and as a result, handicapped patients listed their problems more as social than economic. On the other hand, the Lower Caste group is hard pressed to meet their immediate economic problems and may worry less about things such as physical appearance. In this group, economic problems lower the acceptance of the handicapped patients in the family more than social problems.

The above discussion suggests the importance of rehabilitation of the handicapped patients especially those belonging to Lower Caste group as they are the most affected by their disabilities. Studies have demonstrated the restoration of dignity, status and acceptance of the affected patients once they are economically rehabilitated. ${ }^{30}$ Similarly surgical correction of deformities of leprosy is most rewarding in improving body image and erosion of stigma, functional capabilities and reduction of psychiatric morbidity. ${ }^{31-32}$ Scientific studies have demonstrated that physical attractiveness will bring more success, ${ }^{33}$ respect, ${ }^{34}$ friends, happy marital life ${ }^{35}$ and better social adjustment. ${ }^{36}$ In view of these studies, it is necessary to correct deformities and provide rehabilitation to all the deformed patients. Counselling of patients and their family will help them in understanding the disease and the associated problems leading to better social adjustment. Effective health education to all groups would help in changing attitudes and developing greater understanding of the disease and acceptance of the patients. An understanding of the impact of social inequalities on the life of the affected will help in planning necessary interventions in the antileprosy programme.

\section{Acknowledgments}

The financial support provided by the Damien Foundation, Madras for this study is gratefully acknowledged. The author is thankful to Dr A. M. Kurup, Former Chief Research Scientist, Centre for Social Science Research on Leprosy, GMLF, Wardha for his encouragement and to Dr K. V. Desikan, Lepra Histopathology Centre, Sevagram for his valuable suggestions and help in preparing the final draft. Thanks are also given to the referees for their constructive comments. The secretarial assistance of Ms Kalpana Giawande is highly appreciated.

\section{References}

1 Senart E. Caste in India: The Facts and the System, Translated by S. Denison Ross, Metheun \& co. (London), 1930. 
2 Tumin Melvin M. Social Stratification: The Forms and Fuctions of Inequality, Prentice Hall of India, (New Delhi), 1978.

3 Ghurye GS. Caste and Race in India, Popular Prakashan (Bombay), 1969.

4 Murdoch J. Review of Caste in India, Rawat Publications (Jaipur), 1977.

5 Hutton JH. Caste in India: Its nature, function and origins. Oxford University Press (London), 1963.

6 Yesudian CAK. Health services utilisation in urban India: A Study, Mittal Publications (Delhi), 1988.

7 Quadeer Imrana. 'Health services system: An expression of socio-economic inequalities', Social Action, 1985, 35(3): 199-223.

8 Prabha Ramalinga Swami, 'Women's access in health care': Eco and Pol Weekly, 1987, 22(27): 1075-1076.

9 Banerji D. 'Class inequalities and unequal access to health services in India', Social Action, 1989, 39(3): 215-228.

10 Shivakumar AK, Mukherjee VN. 'Health as development: Implications for Policy, Research and Action', Eco and Pol Weekly, 1993, XXVIII (16): 769-774.

11 Lewis Oscar. 'Village life in Northern India: Studies in a Delhi Village', University of Illinois Press (Urbana), 1958.

12 Joshi Prabhash. 'The all-seeing blind eye' Indian Express, 1982, April 9-12.

13 Kopparty SNM. 'Health status of scheduled castes' Social Change, 1991, 21(1): 82-90.

14 Kopparty SNM. 'Social Inequality and Health Care, Northern Book Centre, (Delhi) 1994.

15 Kopparty SNM. 'Caste and Leprosy: Some observations on knowledge, problems and coping strategy among the affected families'. The Eastern Anthropologist, 1994, 47(2): 109-127.

16 Kopparty SNM. 'Knowledge about leprosy among the families of def ormed patients in caste groups' Health and Population, 1994, 17(1 \& 2): 56-68.

17 Noordeen SK, Lopez Bravo L, Sundaresan TK. 'Estimated number of leprosy cases in the World', Ind J Lepr, 1992, 64(4): 521-27.

18 Mittal BN. Leprosy status report of India 1992, International Leprosy Union (Pune), 1993.

19 Srinivasan H. 'Not by chemotherapy alone'. Indian J Lepr, 1994, 66(2): 209-221.

20 Susman Joan. 'Disability, stigma and deviance'. Soc Sci Med, 1994, 38(1): 15-22.

${ }^{21}$ Goffman E. Stigma: Notes on the management of spoiled identity, Prentice Hall (Englewood Cliffs N J), 1963.

22 Verbrugge Lois M, Jette Alan M. 'The disablement Process'. Soc Sci Med, 1994, 38(1): 1-14.

23 Ashok Kumar and Anbalagan. 'Socio-economic experiences of leprosy patients'. Lepr India, 1983, 55(2): 314-321.

24 Davey TF. 'Psychological aspects of leprosy'. Lepr Rev, 1976, 47: 71-74.

${ }^{25}$ Dwivedi MP. 'A study of medico-social problems of cured cases in the Pandri village of Raipur district, M.P.' Lepr India, 1974, 46(4): 245-252.

${ }^{26}$ Kant VP. 'Socio-economic problems of leprosy patients and their relatives in Gujarat State'. Ind J Lepr, 1984: 56: 889-90.

27 Sabhesan S. 'Disease symbols of leprosy and their psychological consequences'. In Proceedings of the consultative workshop on social science research methods on health behaviour with special reference to leprosy, Centre for Social Science Research on Leprosy, Gandhi Memorial Leprosy Foundation, India, 1988.

28 Selvapandian AJ, Richards J. 'Relationship between occupation and disabilities in leprosy patients'. Ind J Lepr, 1973, XLV(4): 248-254.

29 Shah NB. 'Effects of leprosy on patients work life'. Lepr India, 1965, 37: 386-389.

${ }^{30}$ Gershon W, Srinivasan GR. 'Community-based rehabilitation: An evaluation study'. Lepr Rev, 1992, 63(1): 51-59.

31 Ramanathan U, Malaviya GN, Nootan Jain, Husain S. 'Psychosocial aspects of deformed leprosy patients undergoing surgical correction', Lepr Rev, 1991, 62: 402-409.

32 Jennings WH, Joshi PV, Pandey SD, Mehta JN, Antia NH. 'A socioeconomic study of leprosy surgery cases'. Lepr India, 1975, 47(3): 186-9.

33 Dion KK, Berscheid E, Walser E. 'What is beautiful is good'. J Prs Soc Psychol, 1972, 24: 285-290.

34 Berscheid E, Walster E. 'Beauty and the best'. Psychol Today, 1972, 5: 42-46.

35 Kirkpatrick C, Cotton J. 'Physical attractiveness, age and marital adjustment', Am Sociol Rev, 1951, 16: 8186.

36 Lerner RM, Lerner JV. 'Effects of age, sex and physical attractiveness on child-peer relations, academic performance, and elementary school adjustment'. Dev Psychol, 1977, 13: 585-590. 